\title{
Perception of and adaptation to climate change by farmers in the semi-arid zone of North-eastern Nigeria
}

\author{
Bose, M.M., ${ }^{1}$ Abdullah, A.M., ${ }^{2}$ Harun R, ${ }^{2}$ Jamalani M.A., ${ }^{1}$ Elawad R.E., ${ }^{1}$ \\ Fallah M. ${ }^{1}$ \\ ${ }^{1}$ Air pollution and Eco physiology Lab, Faculty of Environmental Studies, Universiti Putra Malaysia, 43400 \\ UPM Serdang, Selangor, Malaysia \\ ${ }^{2}$ Environmental Forensic Research Centre, Faculty of Environmental Studies, Universiti Putra Malaysia, 43400 \\ UPM Serdang, Selangor, Malaysia \\ Corresponding Author: amakmom@upm.edu.my
}

\begin{abstract}
This study evaluates the farmers' perception and climatic variability using climate record. Various climate change adaptation strategies used by the farmers in the semiarid zone of north-eastern Nigeria were also identified. Forty years of climatic data on temperature and rainfall (1971-2010) from the Nigeria meteorological agency were collected and analyzed using non-parametric Mann-Kendall test. Questionnaire survey was conducted to understand farmers' perception and adaptations in response to changing climate and variability. The results reveled that an increase in annual temperature of $+0.76{ }^{\circ} \mathrm{C}$ from 1971 to 2010 has been recorded in the entire semiarid zone of North-eastern Nigeria, whereas annual rainfall has not exhibited any trend. Surveyed results show that many farmers noticed long-term changes in temperature and precipitation, although farmers' perception on temperature change appeared to be higher than the one observed. However, in order to cushion the effects of climatic variability farmers have adopted a variety of adaptation strategies including soil conservation, change in planting date, agro forestry product, improve crop seedlings, and irrigation.
\end{abstract}

Keywords: Adaptation, climate change, farmers' perception, semiarid zone, north-eastern Nigeria

\section{Introduction}

Climate change is a standout amongst the most genuine natural dangers confronting humanity around the world. It influences agriculture in a few ways, including its control effect on food production, its adverse effects on agricultural productivity in Africa is attributable to the natural climate cycle and human activities [1]. Available evidence shows that climate change is global, likewise its impacts; but the most adverse effects will be felt mainly by developing countries especially those in Africa, due to their low level of coping capabilities, which Nigeria is one of these developing countries [2], [3]. As the planet warms, rainfall patterns shift, and extreme events such as droughts, floods, and forest fires become more frequent, this results in poor and unpredictable yields, thereby making farmers more vulnerable, particularly in Africa [4].

Nigeria is recognised as one of the African countries very vulnerable to climate change [4]-[6]. This is because agriculture is an important sector of its economy, employing about $70 \%$ of the population and contributing significantly to gross domestic product [7]. Also, agriculture in the country is mainly rain-fed, making it vulnerable to the vagaries of weather. The vulnerability of the country is further exacerbated by the high population (about 170 million), two-thirds of the land cover located in drought prone areas and the long coastal land (about $800 \mathrm{~km}$ ) which is prone to sea level rise [5]. Unfortunately, the country has a low adaptive capacity due to low financial, technical and technological capabilities, weak institutions, limited awareness of climate change and the lack of national climate change adaptation policy [8].

The importance of adapting agriculture to climate change in Africa has resulted in a vast amount of research on farmers' perceptions and adaptations to climate change in the continent e.g. [9]-[19]. The overall conclusion of these studies is that most farmers perceive that the climate is changing and are taking up several adaptation measures to reduce the impact. For instance, in a review of climate change adaptation in African agriculture, [20] identified about 104 different adaptation practices used by farmers which are broadly categorised into: farm management and technology; farm financial management; diversification of farm and offfarm activities; government interventions in infrastructure, health and risk reduction; and knowledge management, networks and governance.

While major adaptation measures such as new crops or crop varieties and livelihood diversification are adopted by farmers throughout the continent, others are peculiar to certain regions, and the choice of the adaptation options is influenced by different contextual [10], [11], [14], [16], [21]-[23]. This implies that areaspecific studies on climate change adaptation are necessary. This is also noted by [13] who contended that 
reactions to effects of climate change regularly have a tendency to be limited and setting specific, subsequently obliging that studies on adaptation need to be custom-made to specific connections in light of the fact that an one size fits all result will not work.

However, most research on farmers' adaptation to climate change in Africa has focused on the Sahel region of West Africa partly due to the severe droughts and famines in this region in the 1970 and 1980s [15] and on the rainforest ecological zones. The savannah region, which is severely affected by climate change, is under-represented in the literature. Additionally, [8], [9], [17], [24]-[27], are among the few studies on farmers adaptation in Nigeria. Yet, the results of their findings only looked into perception and the adaptation options without contrasting farmer's perception with the climate trend. Although, few studies in Africa revealed that farmers' perceptions corroborate actual climate trends to a certain extent [12], [15], [28], [29]. Therefore, this study aims to complement existing adaptation studies in Nigeria and Africa by looking at how farmers in the semiarid zone of northern Nigeria perceive of, and adapt to climate change. The main objective of this paper is to study farmer's perception of and adaptations to climate in corroboration to the actual trends in the semiarid zone of northern Nigeria.

\subsection{Study area}

\section{Materials and Method}

The study area covers three states in the North-eastern Nigeria consist of Bauchi $\left(10.50^{\circ} \mathrm{N}, 10.00^{\circ} \mathrm{E}\right)$, Maiduguri $\left(13^{\circ} 10^{\prime}, 11^{\circ} 50^{\prime}\right)$, and Adamawa $\left(9.33^{\circ} \mathrm{N}, 12.50^{\circ} \mathrm{E}\right)$, selected based on the availability of climatic data (Fig. 1). The area defined covers a land area of approximately 103,639 square miles, and represents $29.1 \%$ of the total area of Nigeria (Barbour 1971). Three local government areas, (Ganjuwa, Biu, and Ganye) where selected based on their agro ecological zones from Bauchi, Maiduguri, and Yobe states in North-eastern Nigeria.

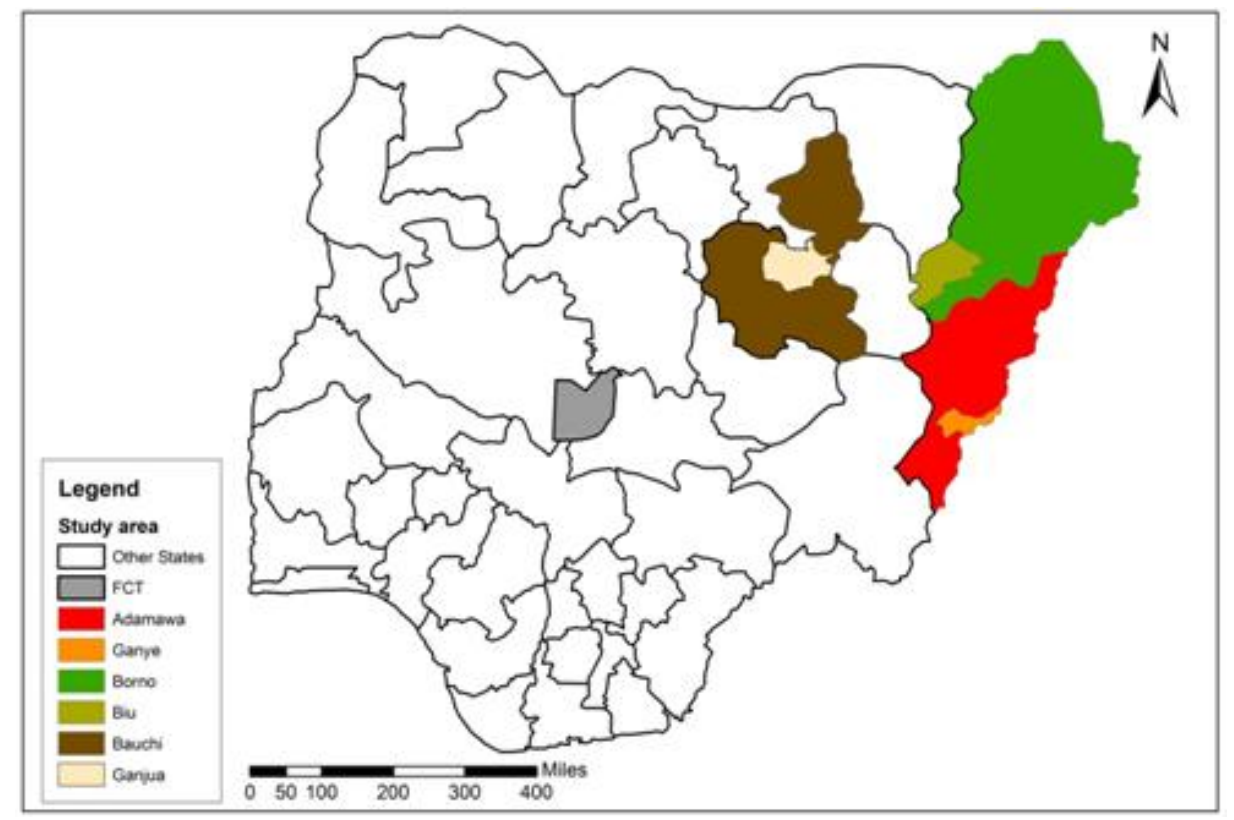

Figure 1 Location of the Study Area in the North-eastern Nigeria

A household survey was conducted from July to October 2013 where 400 farmers were randomly sampled from three farming communities (Ganjuwa, Biu, and Ganye) using the stratified random sampling method. Structured questionnaires was used to investigate whether farmers had noticed long term changes in temperature, rainfall, availability of ground water, drought, wind intensity, length of cold periods and length of dry period in order to ascertain their level of perception. Questions about adaptation and the barriers to adaptation were also posed.

\subsection{Data analysis}

For statistical analysis, descriptive statistics, percentile and 5-point ordinal scale was employed to ascertain the farmers' perception of the climatic variability. However, the farmers perception were corroborated with the actual trend of the climatic variability using a Mann-Kendall trend test which is used to detect longterm trend of the meteorological variables (e.g. temperature and rainfall) in the study area. 


\subsubsection{Mann-Kendall Trend Test}

The basic principle of Mann-Kendall tests for trend is to examine the sign of all pairwise differences of observed values. The Mann-Kendall test is based on the statistic S. Each pair of observed values yi, yj (i>j) of the random variable is inspected to find out whether yi $>$ yj or yi $<y j$. The test statistic for the Mann-Kendall test is given as

$$
S=\sum_{k-1}^{n-1} \sum_{j=k=1}^{n} \operatorname{sgn}(\mathrm{Xj}-\mathrm{Xk})
$$

Where the $x j$ and $x k$ are the sequential data values and $j>k, n$ is the length of the data set and

$$
\operatorname{sgn}(x j-x k)=\left\{\begin{array}{l}
1 \text { if } x j-x k>0 \\
0 \text { if } x j-x k=0 \\
-1 \text { if } x j-x k<0
\end{array}\right.
$$

which is the number of positive differences minus the number of negative differences. Variance of S, computed by

$$
\operatorname{Var}(s)=\left\lfloor n(n-1)(2 n+5)-\Sigma_{t}(t-1)(2 t+5)\right\rfloor / 18
$$

And are asymptotically normal [30], where $t$ is the extent of any given tie and the summation over all ties. For the case that $\mathrm{n}$ is larger than 10 , the standard normal variate $\mathrm{z}$ is computed by using the following equation [31].

$$
\mathrm{Z}=\left\{\begin{array}{l}
\frac{s-1}{\sqrt{\operatorname{Var}(S)}} \text { if } s>0 \\
0 \quad \text { if } \quad s=0 \\
\frac{s+1}{\sqrt{\operatorname{Var}(S)}} \text { if } S<0
\end{array}\right.
$$

Thus, in a two-sided test for trend, at a selected level of significance $\alpha$, the null hypothesis of no trend is rejected if the absolute value of $\mathrm{Z}$ is greater than $\mathrm{z}_{\mathrm{a} / 2}$. In addition to identifying whether a trend exists, the magnitude of a trend was also estimated by a slope estimator b, which was extended by Hirsch [30] from that proposed by Sen [32], defined as

$$
\beta=\operatorname{Median}\left(\frac{x j-x i}{j-i}\right) \text { where } 1<i<j<n
$$

In other words, the slope estimator $\beta$ is the median over all possible combinations of pairs for the whole data set [30]. A positive value of $\beta$ indicates an 'upward trend' (increasing values with time), while a negative value of $\beta$ indicates a 'downward trend' [33], [34].

\subsection{Trend of climatic variability}

\section{Results and Discussion}

Annual temperature displays significant changes, with an upward trend identified in the entire Northeast. The average trend calculated for the study area has a Senslope of +0.76 , implying that an increase in annual temperature of $+0.76{ }^{\circ} \mathrm{C}$ from 1971 to 2010 has been recorded in the entire North-eastern region which is in consistent with [3], who observed an increase of $1.78{ }^{\circ} \mathrm{C}$ from 1901 to 2008 with a more significant increase between 1971 to 2008 in Nigeria (Table 3.1).

Table 3.1 Trend for annual temperature and rainfall 1971-2010

\begin{tabular}{lll}
\hline Statistics & Temperature & Rainfall \\
\hline Mann-Kendall Statistic & 286 & 158 \\
Kendall's Tau & 0.36 & 0.203 \\
Sen Slope & 0.76 & 0.551 \\
P-value (two tailed) & 0.001 & 0.067 \\
Test interpretation & Reject H0 & Accept H0 \\
\hline trend in the series, Ha: There is a trend in the series & &
\end{tabular}

Note: H0: There is no trend in the series $\mathrm{Ha}$ : There is a trend in the series

For annual rainfall, no significant trends was observed in most of the stations, hence these agrees with the conclusions of [3], [35], [36], they did not observe any significant trend for annual totals of different region of the country. Although these trends seem to be consistent over the country, the changes are not always uniform. Therefore, a certain spatial variability from the mean average with a linear trend is observed in the annual temperature trend in the North-eastern Nigeria which indicate increasing trend (Fig. 2). 


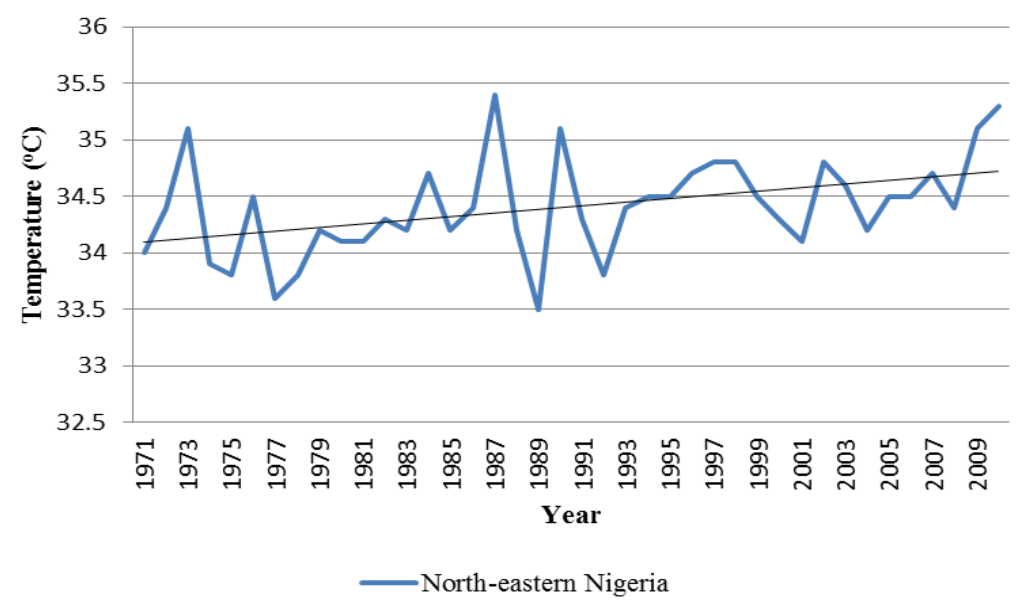

Figure 2 Temperature trend North-eastern Nigeria (1971 to 2010)

\subsection{Farmer's perception of climate change}

Generally, the adaptations strategies used by the farmers are directly connected to the perceived changes in temperature and rainfall events, and this confirms arguments that farmers perception influences the type of adaptation strategies they adopt [11], [21], [37], [38]. The surveyed households were asked for any observed changes in temperature, rainfall, availability of ground water, drought, wind intensity, length of cold periods and length of dry period in order to ascertain their level of perception.

The results of farmers perception on climatic vulnerability presented in (Fig. 3) indicate that $91.2 \%$ of the surveyed farmers have observed increasing temperature while only an insignificant $5.1 \%$ noticed a decreased in temperature, and for $3.7 \%$ of the respondent it remain unchanged. $83.1 \%$ of the farmers perceived a decline in yearly total rainfall. Furthermore, farmers were also asked on other important climate parameters include wind intensity, availability of groundwater, changes in drought, length of cold period, and length of hot period. Almost $92 \%$ of the farmers perceived an increased in length of hot period and a decreased length of cold period, $87.9 \%$ of the farmers perceived an increased in frequency of draught, which may be attributed to the high rate of desertification in the area as reported by the federal ministry of environment [5]. 78\% of the farmers observed a decreased in availability of ground water, while $81.9 \%$ observed an increase in wind intensity over the past 20 years. Similarly, the result indicates that there is a reduction in the number of cold days and an increase in the number of extreme hot days in the study area. It also implies that farmers' indication of an increase in temperature is mainly due to extreme temperature events and a decrease in the number of cold days.

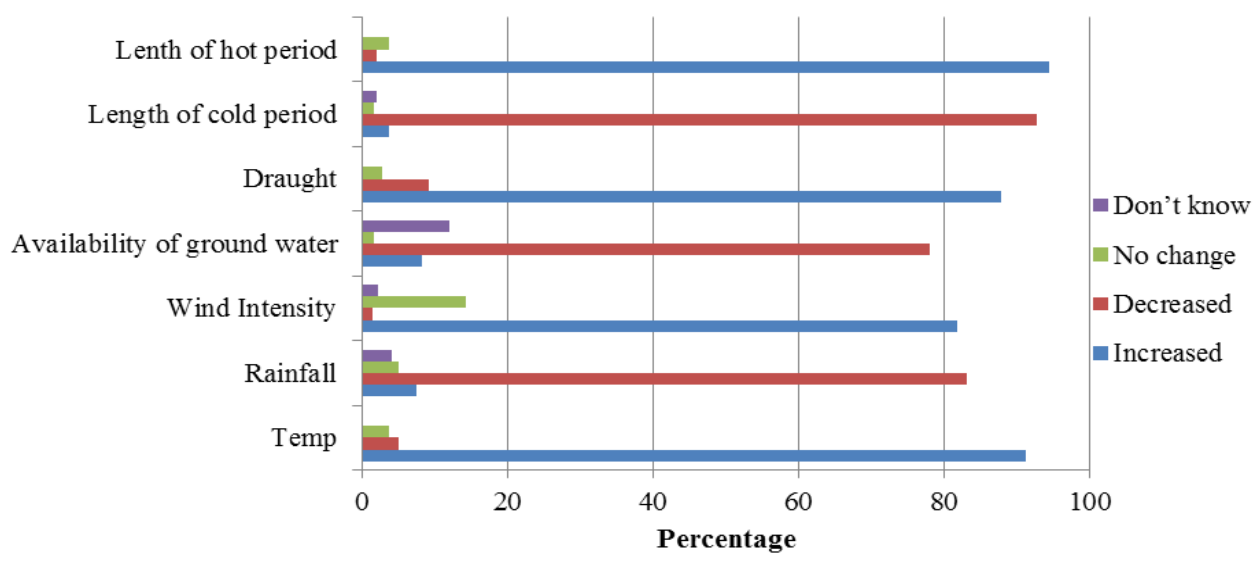

Figure 3 Farmers perception of climatic variability

In general, farmers' perceptions are verified with the analysis of the climatic variability in the previous section, it revealed that farmers' perception on temperature change appeared to be higher than the one observed. In contrast to farmers perception, observed annual rainfall showed insignificant trends.

\subsection{Farm level adaptation strategy}

In order to cushion the effects of climatic variability, farmers take different sorts of measures to adjust with the climatic vulnerabilities. Their practices vary based on their degree of vulnerability, awareness, 
perception, localities, and affordability of resources [22]. In this study, farmers have adopted a variety of adaptation strategies including soil conservation, change in planting date, agro forestry product, improve crop seedlings, mix-cropping, move to a different site, irrigation, and the use chemical pesticides and herbicides (Figure 4).

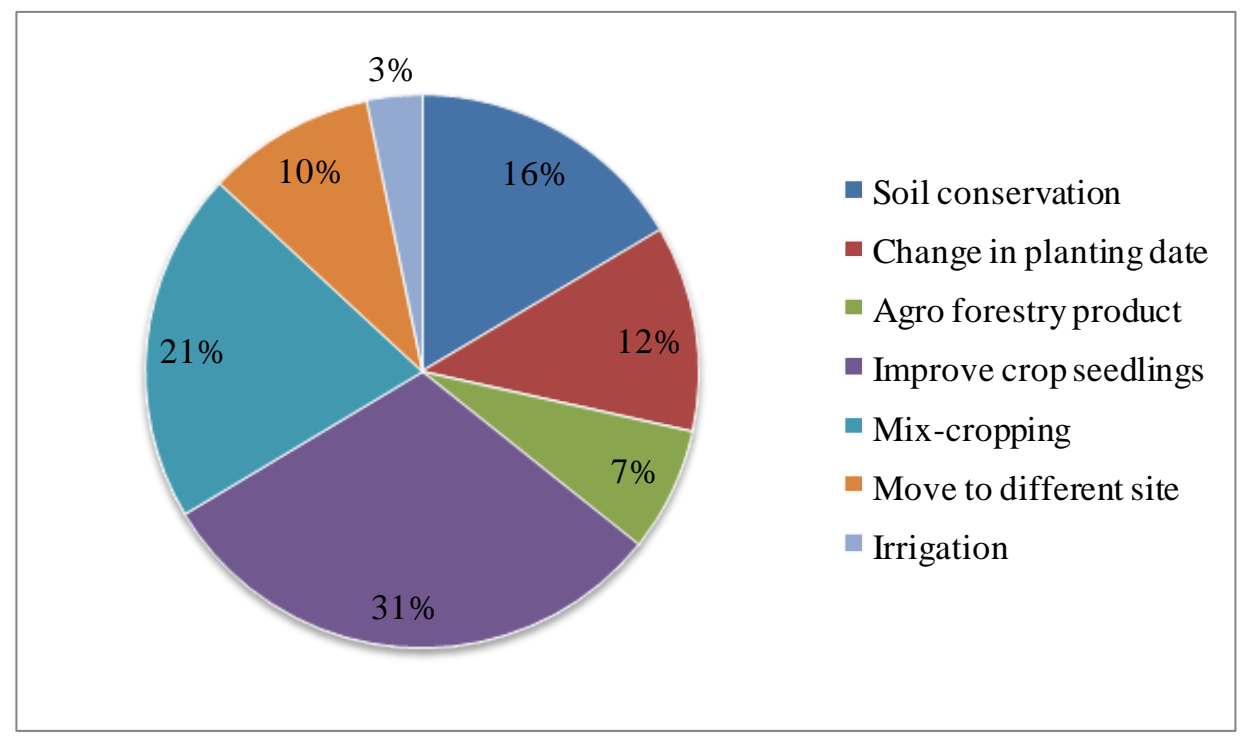

Figure 4 Farmers adaptation strategies

The use of improve seedlings is the most commonly used method, whereas use of irrigation is the adaptation least practiced among the major adaptation methods identified in this study. Greater use of improve crop seedlings as an adaptation method could be associated with the lower expense and ease of access by farmers, while the limited use of irrigation could be attributed to the need for more capital and low potential for irrigation. These adaptation methods mentioned by farmers are similar to the other findings in the climate change adaptation literature [39]; [21][37], [40]; [41] [42] [38].

\section{Conclusion}

The results of the study revealed that an increase in annual temperature of $+0.76{ }^{\circ} \mathrm{C}$ from 1971 to 2010 has been recorded in the semiarid zone of North-eastern Nigeria, whereas annual rainfall has not exhibited any trend. Surveyed results show that many farmers noticed long-term changes in temperature and precipitation, although farmers' perception on temperature change appeared to be higher than the one observed. In contrast to farmers perception, observed annual rainfall showed insignificant trends. However, in order to cushion the effects of climatic variability farmers have adopted a variety of adaptation strategies including soil conservation, change in planting date, agro forestry product, improve crop seedlings, and irrigation.

\section{Acknowledgements}

The authors acknowledge the support of the Nigeria Meteorological Agency (NIMET) for the provision of the Temperature and Rainfall data. We also thank to the anonymous referees for their helpful comments on the original manuscript.

\section{References}

[1]. G. Ziervogel, A. Nyong, B. Osman, C. Conde, S. Cortés, and T. Downing, "Climate Variability and Change $\square$ : Implications for Household Food Security AIACC Working Paper No . 20,” Washington DC USA, 20, 2006.

[2]. N. Manson, "The Impacts of Trade Liberalization on Poverty in Nigeria $\square$ : Dynamic Simulations in a CGE Model," JEL Classif., no. October, 2006.

[3]. P. A. O. Odjugo, "ClimATE CHANGE AND GLOBAL WARMING $\square$ : THE NIGERIAN PERSPECTIVE,”J. "Sustainable Dev. Environ. Prot., vol. 1, no. 1, pp. 6-17, 2011.

[4]. IPCC, "Climate Change 2007: Synthesis Report. Contribution of the Working Groups I, II and III to the Fourth Assessment Report of the Intergovernmental Panel on Climate Change," Geneva, Switzerland, 2007.

[5]. FMOE, "NATIONAL ENVIRONMENTAL, ECONOMIC AND DEVELOPMENT STUDY ( NEEDS ) FOR CLIMATE CHANGE IN NIGERIA ( Final Draft )," Abuja, Nigeria, 2010.

[6]. S. Huq and J. Ayers, "Critical list: the 100 nations most vulnerable to climate change," Sustain. Dev. Opin. Int. Inst. Environ. Dev., 2007.

[7]. Apata T.G, "Effects of Global Climate Change on Nigerian Agriculture $\square$ : An Empirical Analysis," CBN J. Appl. Stat., vol. 2, no. 1, pp. 31-50, 2010.

[8]. P. A. O. Odjugo, "Adaptation to Climate Change in the Agricultural Sector in the Semi-arid Region of Nigeria," in 2nd International Conference: Climate, Sustainability and Development in Semi-arid Regions August 16 - 20, 2010,2010 , pp. 1-14. 
[9]. S. K. . and A. A. . Apata T.G, "Analysis of Climate Change Perception and Adaptation among Arable Food Crop Farmers in South Western Nigeria," in International Association of Agricultural Economists' 2009 Conference, 2009, pp. 1-15.

[10]. B. Barbier, H. Yacouba, H. Karambiri, M. Zoromé, and B. Somé, "Human vulnerability to climate variability in the Sahel: farmers' adaptation strategies in northern Burkina Faso.," Environ. Manage., vol. 43, no. 5, pp. 790-803, May 2009.

[11]. E. Bryan, T. T. Deressa, G. a. Gbetibouo, and C. Ringler, "Adaptation to climate change in Ethiopia and South Africa: options and constraints," Environ. Sci. Policy, vol. 12, no. 4, pp. 413-426, Jun. 2009.

[12]. B. Y. Fosu-Mensah, P. L. G. Vlek, and D. S. MacCarthy, "Farmers' perception and adaptation to climate change: a case study of Sekyedumase district in Ghana,” Environ. Dev. Sustain., vol. 14, no. 4, pp. 495-505, Feb. 2012.

[13]. E. Hisali, P. Birungi, and F. Buyinza, "Adaptation to climate change in Uganda: Evidence from micro level data," Glob. Environ. Chang., vol. 21, no. 4, pp. 1245-1261, Oct. 2011.

[14]. O. Mertz, C. Mbow, A. Reenberg, and A. Diouf, "Farmers' perceptions of climate change and agricultural adaptation strategies in rural Sahel.," Environ. Manage., vol. 43, no. 5, pp. 804-16, May 2009.

[15]. C. T. West, C. Roncoli, and F. Ouattara, "LOCAL PERCEPTIONS AND REGIONAL CLIMATE TRENDS ON THE CENTRAL PLATEAU OF BURKINA FASO,” L. Degrad. Dev., vol. 304, no. April, pp. 289-304, 2008.

[16]. T. B. Below, K. D. Mutabazi, D. Kirschke, C. Franke, S. Sieber, R. Siebert, and K. Tscherning, "Can farmers' adaptation to climate change be explained by socio-economic household-level variables?," Glob. Environ. Chang., vol. 22, no. 1, pp. 223-235, Feb. 2012.

[17]. J. A. Tambo and T. Abdoulaye, "Smallholder farmers' perceptions of and adaptations to climate change in the Nigerian savanna," Reg. Environ. Chang., vol. 13, no. 2, pp. 375-388, Sep. 2012.

[18]. C. Ifejika Speranza, B. Kiteme, P. Ambenje, U. Wiesmann, and S. Makali, "Indigenous knowledge related to climate variability and change: insights from droughts in semi-arid areas of former Makueni District, Kenya," Clim. Change, vol. 100, no. 2, pp. 295-315, Sep. 2009.

[19]. T. T. Deressa, R. M. Hassan, and C. Ringler, "Perception of and adaptation to climate change by farmers in the Nile basin of Ethiopia," J. Agric. Sci., vol. 149, no. 01, pp. 23-31, Aug. 2010.

[20]. S. S. Below Till, Artner Astrid, Siebert Rosemarie, "Micro-level Practices to Adapt to Climate Change for African Small-scale Farmers," Washington DC. USA, 00953, 2010.

[21]. T. T. Deressa, R. M. Hassan, C. Ringler, T. Alemu, and M. Yesuf, "Determinants of farmers' choice of adaptation methods to climate change in the Nile Basin of Ethiopia," Glob. Environ. Chang., vol. 19, no. 2, pp. 248-255, May 2009.

[22]. M. M. Alam, C. Siwar, R. I. Molla, B. Talib, and M. E. Toriman, "Paddy farmers' adaptation practices to climatic vulnerabilities in Malaysia," Mitig. Adapt. Strateg. Glob. Chang., vol. 17, no. 4, pp. 415-423, Nov. 2011.

[23]. J. A. Tambo and T. Abdoulaye, "Climate change and agricultural technology adoption: the case of drought tolerant maize in rural Nigeria," Mitig. Adapt. Strateg. Glob. Chang., vol. 17, no. 3, pp. 277-292, Oct. 2011.

[24]. I. J. Ekpoh and E. Nsa, "Extreme Climatic Variability in North-western Nigeria: An Analysis of Rainfall Trends and Patterns," J. Geogr. Geol., vol. 3, no. 1, pp. 51-62, Aug. 2011.

[25]. T. C. Nzeadibe, C. L. Egbule, C. A. Nnaemeka, \&, and V. C. Agu, "Climate Change Awareness and Adaptation in the Niger Delta Region of Nigeria," Nairobi Kenya, No 57, 2011.

[26]. N. A. Sofoluwe, A. A. Tijani, and O. I. Baruwa, "Farmers 'perception and adaptation to climate change in Osun State , Nigeria," African J. Agric. Res., vol. 6, no. 20, pp. 4789-4794, 2011.

[27]. D. K. ONYENEKE, R. U \& MADUKWE, "ADAPTATION MEASURES BY CROP FARMERS IN THE SOUTHEAST RAINFOREST ZONE OF NIGERIA TO CLIMATE CHANGE,” Sci. World J., vol. 5, no. 1, pp. 32-34, 2010.

[28]. E. Meze-hausken, "Contrasting climate variability and meteorological drought with perceived drought and climate change in northern Ethiopia," Clim. Res., vol. 27, pp. 19-31, 2004.

[29]. G. A. Gbetibouo, R. M. Hassan, and C. Ringler, "Modelling farmers' adaptation strategies for climate change and variability: The case of the Limpopo Basin, South Africa," Agrekon, vol. 49, no. 2, pp. 217-234, Jun. 2010.

[30]. R. M. Hirsch and J. R. Slack, "A Nonparametric Trend Test for Seasonal Data With Serial Dependence," Water Resources Research, vol. 20, no. 6. pp. 727-732, 09-Jun-1984.

[31]. E. M. Douglas, R. M. Vogel, and C. N. Kroll, "Trends in floods and low fows in the United States $\square:$ impact of spatial correlation," J. Hydrol., vol. 240, pp. 90-105, 2000.

[32]. Sen Pranab Kumar, "Robustness of Some Nonparametric Procedures In Linear Models," Analls Math. Stat., vol. 39, no. 6, pp. 1912-1922, 1968.

[33]. Xu, J. Y. Li, and C. M. Liu, "Long-term trend analysis for major climate variables in the Yellow River basin," Hydrol. Process., vol. 21, no. May, pp. 1935-1948, 2007.

[34]. Z. X. Xu, Z. Liu, G. Fu, and Y. Chen, "Trends of major hydroclimatic variables in the Tarim River basin during the past 50 years," J. Arid Environ., vol. 74, no. 2, pp. 256-267, Feb. 2010.

[35]. P. A. O. Odjugo, "Regional evidence of climate change in Nigeria," J. Geogr. Reg. Plan., vol. 3, no. June, pp. 142-150, 2010.

[36]. U. C. Udo-inyang and I. D. Edem, “Analysis of Rainfall Trends in Akwa Ibom State , Nigeria," J. Environ. Earth Sci., vol. 2, no. 8, pp. 60-71, 2012.

[37]. K. P. Maddison David, Manley Marita, "The Impact of Climate Change on African Agriculture A Ricardian Approach," Pretoria, South Africa, CEEPA Discussion Paper No. 10, 2007.

[38]. N. C. Hassan Rashid, "Determinants of African farmers' strategies for adapting to climate change: Multinomial choice analysis," African J. Agric. Resour. Econ., vol. 2, no. 1, pp. 83-104, 2008.

[39]. B. Bradshaw, H. Dolan, and B. Smit, "Farm-Level Adaptation to Climatic Variability and Change: Crop Diversification in the Canadian Prairies," Clim. Change, vol. 67, no. 1, pp. 119-141, Nov. 2004.

[40]. P. Kurukulasuriya and R. Mendelsohn, "A Ricardian analysis of the impact of climate change on African cropland," African J. Agric. Resour. Econ., vol. 2, no. 1, pp. 1-23, 2008.

[41]. A. R. Sarker, "Impacts of Climate Change on Rice Production and Farmers ' Adaptation in Bangladesh," UNIVERSITY OF SOUTHERN QUEENSLAND, 2012.

[42]. C. Nhemachena and R. Hassan, "Micro-Level Analysis of Farmers ' Adaptation to Climate Change in Southern Africa," Washington, DC., IFPRI Discussion Paper No. 00714., 2007. 